\title{
Faithful dissent and religious education in Canadian Catholic schools: A response to McDonough
}

\author{
Richard Rymarz* \\ St. Joseph's College, University of Alberta, Canada. \\ McDonough $\uparrow$ proposes that one way of invigorating religious \\ education in Canadian Catholic high schools is to present a wider \\ range of views under the ambit of Catholic teaching including \\ those which are currently regarded as dissenting opinions. These \\ are not in keeping with official teaching but enjoy support in the \\ wider Catholic community. In response to this it is argued that a \\ better understanding of the contemporary discourse on religious \\ education in Catholic schools would accommodate a thoughtful \\ engagement with a range of views. This is in keeping with an \\ educative model of religious education which can distinguish \\ between the educative and catechetical goals of RE. A stronger \\ focus on the educative aspects of religious education is proposed as \\ a more direct way of improving the quality of religious education \\ in schools.
}

\section{Key words}

Religious education, Catholic schools, dissenting positions, educational model.

$\dagger$ G. McDonough. 'Can there be 'faithful dissent' within Catholic religious education in schools?’ ISCE Vol 1. No 2 October 2009

The article by McDonough raises several important conceptual issues, especially for the manner in which religious education is conducted in contemporary Canadian Catholic high schools. In comparative terms Canada lacks a critical network of scholars who engage in the questions surrounding religious education in Catholic schools and in this vein McDonough's contribution is a welcome addition to what will hopefully developed into a growing discourse (Rymarz 2012A). The basic contention of the author is that religious education in Canadian Catholic high 
schools would be enhanced if dissenting positions were included as part of the curriculum. The rationale beginning that this would make religious education more like other subject disciplines, especially in how they reflect 'progressive, student centred methods' (188).

To support his notion of progressive methods McDonough references the work of John Dewey rather than the substantial contemporary literature. This leads to my first general reflection on the paper, namely, that it is would be greatly strengthened by a more vigorous integration with published research (Reigeluth and Carr-Chellman 2009). To be sure Dewy is a well known educational philosopher but you would be hard pressed to sustain an argument for a particular type of contemporary pedagogy based on his work alone. In a similar vein, and a point that I will return to later, the paper would be greatly strengthened if the considered international literature of how religious education in Catholic schools is conducted (Peter 1998; Flynn and Mok 2002; Hull 2005; Schweitzer. 2006; Zibbertz et al. 2009). An engagement with this literature would put the question of the content range of religious education in Catholic schools in the context of much wider and well established discussion that sees the goals of Catholic education in educational rather than catechetical terms. Seeing religious education in this way meets many of the objections raised by McDonough and re orientates the discussion to questions of how to better teach RE

\section{Methodological Issues}

As an empirical piece of research this paper does not follow the conventions of published work of this type. The paper reports on interviews with fourteen participants but due to a lack of 
information provided, the data should be approached with some caution. The fourteen participants in the study are identified as high school teachers from publicly funded Canadian Catholic schools. There are, however, significant differences within publically funded Catholic schools. Do the teachers interviewed in this study, for example, work in a large, well established, highly urban, multicultural Catholic schools in Toronto or in a small, remote Catholic schools with a high indigenous enrolment in the North West territories? Both schools are publically funded but without further identifying information it is impossible to distinguish between two very different perspectives. In a similar vein, we have no indication on; the educational background of the participants, how long have they been teaching in Catholic schools, how long have they been teaching religion, how were they recruited to the study or whether they have particular qualifications to teach religious education? Such information if supplied would have enhanced the quality of the data analysis.

Interviews followed a semi structured pattern and were analyzed for themes according to recurring patterns of phrases and ideas expressed. This suggests some type of qualitative software was used as an analytical tool. No information is given as to why fourteen participants were selected and if this was the number at which point saturation of interview data ${ }^{1}$ occurred. I suspect saturation was not achieved as the reported comments of the participants still seem to be relatively disparate. No information is given as to where the interviews were conducted or how long they took. The second point here is particularly important because analysis of interview data is quite different for extensive interviews of an hour or more when compared to shorter interviews. Without labouring the point, similar comments could be made about the method of analyses of the interviews. Analysis of themes covers a wide variety of approaches, each with a 
differing emphasis but none of this information is provided by the author. To conclude these methodological points, the author's use of empirical terminology is loose. For instance, in a study of fourteen participants, it is incorrect to state that one respondent constitutes an exemplary case study (p 194).

\section{What goes on in RE in Canadian Catholic schools today?}

Throughout the paper McDonough makes a number of strong but unsubstantiated assertions about Catholic education. These go to the heart of his argument. For instance on p190 we read "In Catholic education the traditional, conservative view of education holds that students are to 'learn facts' of the Church and receive the 'deposit of faith' so that they can participate in it". Or on page 188 he comments, "religion classes do not encourage students to critique or even look for any weaknesses in Church teaching..." It is important for McDonough to provide strong justifications for assertions such as these as they form the basis of his contention that Catholic schools are engaged in some type of undemocratic indoctrination of students and that better educative models exist. This is an easy case to make if the basic assumption is correct. In fact, it is far from accurate to describe the goals of Catholic education in such terms. McDonough does provide some support for his case in the views of participants in the study but this can hardly be taken as indicative of a Catholic approach. In an initial discussion, views on what constitute a Catholic view of education need to grounded in either authoritative Church documents or more particularly in curriculum documents approved for use in Catholic schools (RDECS 1988;

CSTTM 1997; ISG 1998). There is ample evidence of use of these documents in Canadian Catholic schools and McDonough's case would be substantially strengthened if he could find support for his contentions in them. In comparison to other countries there is a dearth of information on how religious education is taught in Canadian Catholic schools ${ }^{2}$ (Rymarz 2012). 
In light of the lack of a strong, local empirical foundation, this discussion needs to be guided by a wider international literature which centres on how religious education is taught. Although not directly referring to the Canadian context it does provide an overarching framework for discussion on the innovative suggestions that McDonough offers.

Much of this wider literature would not recognize the basis of McDonough's claims on the conservative nature of Catholic education and its lack of concern for authentic and critical engagement with the cognitive and experiential world of students. Over the past forty years the conceptual basis for the teaching of religious education in Catholic schools has shifted substantially and there are currently new proposals that extend this development even further (Rossiter 2010; 2011). To illustrate this point, let me give just two examples, one major conceptual case and one minor pedagogical case of a very substantial literature which examines the evolving role of Catholic religious education and the type of pedagogy that is consistent with these goals. One very well known conceptual schema has been developed over many years by the Irish American theologian Thomas Groome. Groome would be aghast to see the goals of Catholic education described in the terms that McDonough employs. Groome's approach is widely used throughout the world, and certainly in Canada, as a framework for religious education in the classroom (Mulligan 2005). It is not a universal approach, and indeed has drawn some criticism (Ryan and Malone 1996). This simply underlines the point that within a Catholic understanding of religious education there are a variety of approaches which can accommodate contemporary insights on student learning and quality teaching (Mayer 2005; Phillips and Soltis 2009). Most of these do not arise out of a particularly conservative view of the curriculum or the place of the learner within it. They are part of a historical process that has 
seen religious education in Catholic schools move toward more educative models (Rummery 1977; Buchanan 2005).

For Groome the basis of religious education is a critical engagement between the learner, their experience and the story of the faith tradition (Groome 1980; 1991). This engagement proceeds on the basis that the learner brings with him or her a range of experiences and prior knowledge that informs and directs future understanding. It is within this context that a dialogue with the story of the Christian tradition is accessed. Groome's method places great emphasis on the notion of praxis, which in turn, is derived from Habermas' conception of critical theory (Habermas 1972). In this perspective knowing and cognitive interest are closely related. To be sure, much of human knowing is based on what can be called technical knowledge. This is important, however, as the acquisition of concepts and vocabulary establishes a base for higher learning. This idea has some overlap with Vygotsky's notion of the need for the teacher to scaffold learning with clear structure and support (Vygotsky 1987; Chaiklin, 2003). The goal here is not to suffocate student directed learning but to provide a platform for it. This is achieved by enabling students to acquire skills and competencies used in later higher learning. It is worth noting that McDonough takes a very critical stance toward such a developmental approach. He equates it with what he describes as a Platonic understanding, where learners are seem as empty vessels to be filed with required knowledge ( $\mathrm{p} 192$ ). This is only so if learning stops at this technical phase and this is certainly not the case with the critical learning theory developed by Habermas and modulated by Groome for religious education. 
The second level of cognitive interest is based on a developing hermeneutic, where the inner workings of a discipline are organized and interpreted. This type of activity would cover many of goals of the contemporary classroom and is commonly described by the term, subject mastery. This is achieved when technical knowledge is placed within a learning context and integrated with prior knowledge. The confidence of students rises as they see what has been learned against a broader template of prior experience. It is in the third level, however, where emancipatory knowledge is developed. This encourages new connections and understanding based on a critical engagement and deep knowledge of the discipline under review. Lovat $(2009,21)$ encapsulates this view well when he writes, " One has to delve deeply, to gain points of view and counter -points of view, to read widely on any topic, to go out and investigate, research survey...no evidence is accepted lightly, nothing is taken for granted nor any authority beyond being accountable, including the authority of the teacher". In this light, Catholic schools that follow Groome's general approach seek to critically engage with the questions, concerns and thoughts of students. In Groome's model we see the clear outline and influence of Habermas's critical theory with its emphasis on emanciptory knowledge. Stage four of Groome's Shared Christian Praxis, for example, establishes a dialogue between the inspirational story and the participants story. This creates a forum for learning that seems to be a long way from the type of classroom dynamic that McDonough sees as normative for religious education in Catholic schools.

Groome provides one conceptual basis for understanding how religious education in Catholic schools is conducted. Rymarz (2004) provides an example of how a commitment to teaching about hard or controversial topics ${ }^{3}$ in the religious education curriculum can be translated into pedagogical practice. Often controversial or hard topics in religious education are formative of a 
whole world view and as such form a critical part of the religious education curriculum in Catholic schools. When these topics are not addressed, the curriculum lacks coherence and could be one of the reasons that religious education in Catholic schools, in many contexts, seems to lack sufficient depth of content (Francis 2002; Rymarz 2007) Rymarz (2004) based his approach on a eight fold model that was designed to encourage teachers in Catholic schools to tackle controversial issues. The rationale is that for many students these issues are prominent and, as a pedagogical principle, they need to be explicitly addressed with in order for effective learning to take place. Stage four of the process explicitly asks teachers to determine prior student learning and opinions on topics and see these as the foundation for an engaged pedagogy.

\section{Presenting Church Teaching}

One key distinction between the approaches that outlined here and what McDonough proposes seems to be what status official Church's teaching has. When McDonough suggests incorporating a certain range of dissenting positions into the curriculum, it is assumed that he means that these are presented as one alternative in a range of Catholic options. If as McDonough argues, however, there is a need to democratize the curriculum in Catholic schools then why restrict the presentation of dissenting positions to moral questions? If indeed McDonough's use of Poretelli is to be followed and a case made for progressive democratic methodologies which see the child in epistemic terms as bring able to construct his or her own knowledge them why should this construction be hindered by the conservative imposition of any ideology or dogmatic teaching? This is especially so when we consider the preexisting knowledge of many young Catholics today on dogmatic questions. It is true to say that on many 
moral questions the views of young Catholics are not in accord with magisterial teaching (Bibby 1993; O’Toole 1996; Hoge et al 2001; Bibby 2009). McDonough argues that this incongruence should form the basis of a more student centred curriculum in religious education. There are, however, many other issues where there is a disparity between Church teaching and contemporary belief and practice. One of the most outstanding of these is beliefs about God. In what is becoming a classic study Smith and Denton (2005) characterized one of the definitive beliefs of teenagers today as Deism. God here is seem as a distant figure, imbuing the universe but in an amorphous way, a type of benign influence for good in the universe. Smith and Denton point out that this view although widespread and resilient is almost a polar opposite of the classical Christian view of God. The orthodox Christian view of God found in scripture and developed in subsequent centuries, most notably by Augustine, is of a personal God. This God can be known and can enter into personal relationships (Dean 2010.). The point that I wish to emphasize is the difference between the views of many young people and traditional Christian teaching (Smith and Snell 2009).

In McDonough's schema incorporating, and presumably arguing for, Deism in the formal religious education curriculum would not be possible as this would appear to be what he calls infallible teaching ${ }^{4}$. This raises several issues. Strictly speaking the definition of say Christ as the second person of the Trinity, a quintessential anti Deist position, has not been infallibly proclaimed, at least not on terms of the definition of the First Vatican Council (Pottmeyer 1988). It falls under the ordinary magisterial teaching of the Church. If the author is going to rely on ecclesiological terms such as infallible and non infallible he needs to provide much more detail as to which dissenting positions are included and what are not. The underlying point is, 
however, a philosophical one. Having argued that there are a range of dissenting opinions on important questions amongst Catholic youth then why include some of these in revised RE curriculum documents and not others? If the opposing epistemology to that of the preferred democratic progress model is one where children are seen as empty vessels where externally determined knowledge is inserted (p. 190) then the Church sanctioned status of some of this information should have little bearing on what is be included in the formal curriculum.

For Groome and in the pedagogical example provide by Rymarz the official teaching of the Church - or the Church's story - is presented as a normative position and the teacher's task is to present this in an educationally sophisticated way. This does seem to be a consistent position and within the bounds of religious education in a Catholic high school. The Catholic Church, along with other major religious faiths, has always claimed for itself the right to define its own beliefs and practices. Students and parents who are part of the community of Catholic schools are entitled to a religious education where the positions of the Catholic Church are clearly stated. This does not mean that other views are not put but it does offer the official Church teaching a special place in the curriculum, or what Pollefeyt and Bouwens $(2010,209)$ would call, “A preferential option for the Catholic message". The success, however, of religious education in Catholic schools is not measured by how many students eventually subscribe to the official view. The principal focus is to present a well conceived and taught programme that is based on improving student understanding. Furthermore, a distinction needs to be made between the educational and catechetical goals of religious education in Catholic schools. One way of doing this is to see them as distinct but complementary and to distinguish between cognitive and affective outcomes. This helps to ensure that the focus of classroom learning remains on the 
cognitive but at the same time acknowledges that affective goals, which often correlate with catechesis, are not overlooked (Hyde and Rymarz 2007; Engebretson et al. 2008)

A theory of religious education in Catholic schools which recognizes the fundamental distinction between catechetical and cognitive goals was proposed by Rossiter (1982). In a Catholic high school, in this view, the goal of religious education is primarily educative, that is, to provide students with a strong learning environment which increases their understanding and knowledge. For some students this process will also be catechetical, in that it builds on their preexisting faith commitment (Rossiter 1997). For other students, however, the educative process does not have a specifically catechetical aspect. The goal here is to assist the growth of knowledge. In either case, however, the focus of classroom religious education is on creating a quality learning environment. A major part of this would involve presenting a range of views that reflect the experiences and existential questions of students.

To illustrate how cognitive and affective goals can assist in catechesis while keeping the primary focus on cognitive outcomes, consider an example such as teaching on Christological themes. This is a topic that is germane to many religious education programmes in Catholic schools (Astley and Francis 1996; Walshe 2005; Rymarz 2007A). Teaching about Jesus should aim, amongst other things, to give students a good understanding of the historical context in which he lived, his place in scripture, some underlining theology such as the notion of Christ as both God and man. This list could be amplified but the point to stress is that all of these outcomes point to cognitive processes that can be addressed to all students. Students in the class could, however, receive this teaching in different ways depending on, amongst other things, their religious background. In terms of framing the aims of the lesson, however, the emphasis should be on the 
cognitive aspects which can be encapsulated by age appropriate outcomes for each lesson written using Bloom's taxonomy (Bloom 1956; Anderson and Krathwohl 2001).

\section{Educational Focus}

McDonough claims that presenting some dissenting positions will make learning more attractive to students. Whether this is the case is an open question and one that could be illuminated by further research. It does, however, raise a number of issues about how best to improve classroom religious education. My emphasis would be on improving, in the first instance, the quality of curriculum resources and materials along with improving the skills and competencies of RE teachers (Hopkins et al. 1997; Baumfield 2005). There is nothing to suggest that the widely reported deficiencies in content knowledge and pedagogical training in religious education teachers in Canada is any different from that in other parts of the world. (Grace 2003; Rymarz 2012). In order to improve the quality of religious education, therefore, the primary focus should be on improving the overall cognitive framework in which teachers operate along with specialist training of RE teachers. In Alberta, for example, a number of school boards, but certainly not all, insist that teachers who work in Catholic schools have at least two units in their undergraduate programme that focus on theology or religious education. This is a positive development. Two undergraduate units, however, do not place the prospective RE teacher on an equal footing with teachers who are working in other subject disciplines.

Following on from this I would argue that some of the concerns of the participants in this study are well-founded and cannot be dismissed as an attempt by an intellectual elite to preserve a 
conservative epistemology ( $p$ 193). One of these concerns is the complexity of controversial issues for both underprepared teachers and students who do not have strong religious education background. One of the most interesting but relatively under-researched questions in religious education is: Why do adolescents and young adults lack a coherent content knowledge of religion? This is a phenomenon of wide ranging proportions. Davie $(1999,83)$, writing from a European perspective, puts the problem in these terms: "an ignorance of even the basic understandings of Christian teachings is the norm in modern Europe, especially among young people; it is not a reassuring attribute". Smith and Denton (2005) have remarked that one of the features of adolescents in the United States is that they were often unable to articulate their views on religious beliefs. This appeared to be a particular issue for Catholic teenagers, despite attending Catholic schools or being involved in after hours education programmes such those provided by the Confraternity of Christian Doctrine (CCD). In the absence of specifically Canadian data there is no reason to suppose that the difficulties facing teenagers in Europe and the United States are significantly different for Canadian teenagers attending Catholic schools. It seems that one way of addressing this cultural reality is to focus on increasing the number of well taught units in the high schools religious education curriculum. This illustrates once again that the discussion of religious education in Catholic schools needs to be more centred on educational questions. In doing this we are recognizing, in an educative model, the complexity of material that is being presented to students. 


\section{Conclusion}

The perennial issue facing religious education in Catholic schools is how best to maintain and improve the quality of what students experience. There are a number of conceptual models which allow for an engaged and educationally sophisicated approach to be undertaken. Most of these take into account dissenting opinions within the framework of a special place for official Catholic teaching. In this sense I think the central concern of McDonough paper is misplaced. A greater concentration on dissenting opinions will not in my view result in an improvement in the quality of religious education. Much more likely to be successful is an ongoing commitment to improving the educational quality of classroom religious education. The way to best achieve this is to pursue a strongly educational vision of religious education. This does not preclude other views but places classroom teaching within the context of a well presented, reflective Catholic perspective which is in keeping with the goals of Catholic education.

An important part of an educational emphasis is an ongoing commitment to raise the level of teacher skill and competence and a more focused discussion of how to better teach the curriculum. This principle is not comprehensive or particularly profound but it does see the issue in educational terms by articulating the desire to help students better understand their religious and spiritual questions within the broad framework of the Catholic religious tradition. This is entirely within the scope of schools with a particular religious focus. What students do with this knowledge is a broader question but one that needs to be discussed in the context of Catholic schools in the wider culture. 
NOTES

1 Saturation of interview data is a concept derived from Grounded Theory. Glaser (1999) describes this as the point in a series of interviews where no new data is being revealed and participants are repeating previously noted themes. Following a ground theory paradigm it is not possible to set a number of interviews before the research has begun as the researcher does not know in advance at what point saturation will occur. .

2 Rymarz (2012) points out a number of reasons for this lack of research. These relate to relatively weak institutional support for religious education in Canadian Catholic schools. For instance, elected Catholic Schools Boards who have overall responsibility for governance of schools do not make funds available for research into religious education.

${ }^{3}$ Examples of hard topics in religious example include teaching about the Trinity, the problem of evil and human redemption, the interface between science and religion.

${ }^{4}$ McDonough relies on Pilarczyk's (1986) notion of hierarchical truth, 'those truths about faith and morals which have been proposed as certainly true, even though they have not been the object of a specific and formally infallible definition' (198). It is assumed that the author would include teachings about the Trinitarian nature of God in this category.

Notes on contributor

Richard Rymarz

Peter and Doris Kule Chair in Catholic Religious Education, St Joseph's College, University of Alberta and Adjunct Professor Australian Catholic University.

\section{References}

Anderson, L and Krathwohl, D. (Eds.) (2001). Taxonomy of learning, teaching and assessment: A revision of Bloom's taxonomy of educational outcomes. New York: Longman.

Astley, J and Francis, L. (1996). A level gospel study and adolescent images of Jesus, in L Francis, W. Kay and W. Campbell (Eds) Research in Religious Education. Macon GA: Gracewing and Smyth \& Helwys Publishing,239-247.

Baumfield (2005) Disciplinary knowledge and religious education. British Journal of Religious Education. 27(1). 3-4.

Bibby, R. (1993). Unknown gods: The ongoing story of religion in Canada. Toronto: Stoddart.

Bibby, R. (2009). The emerging millennials: How Canada's newest generation is responding to change \& choice. Lethbridge, AB: Project Canada Books. 
Bloom. B. (Ed.) (1956). Taxonomy of educational outcomes. New York: Longman, Green \& Co.

Buchanan, M.T. (2005). Pedagogical drift: The evolution of new approaches and paradigms in religious education. Religious Education 100 (1), 20-37.

Chaiklin, S. (2003). The zone of proximal development in Vygotsky's analysis of learning and instruction, in 'A. Kozulin, B. Gindis, V. Ageyev, and Miller, S. (Eds), Vygotsky's educational theory in cultural context. Cambridge: Cambridge University Press, 65-82.

CSTTM (1997) - The Catholic school on the threshold of the third millennium. Congregation for Catholic Education. Obtained from http://www.vatican.va/roman_curia/congregations/ccatheduc/documents/rc_con_ccatheduc_doc 27041998_school2000_en.html

Davie, G. (1999). Europe: The exception that proves the rule, in Peter Berger (Ed), The desecularization of the world. Grand Rapids, Michigan: Eerdmans.

Dean, K. (2010). Almost Christian: What the faith of our teenagers is telling the American Church. New York: Oxford University Press,

Engebretson, K., Buchanan, M., DeSouza, M and Rymarz, R. (2008). Cornerstones of Catholic secondary religious education. Terrigel, NSW: David Barlow Publications.

Francis, L. (2002). Catholic schools and Catholic values? A study of moral and religious values among 13-15 year old pupils attending non-denominational and Catholic schools in England and Wales. International Journal of Education and Religion, 3(1), 143-151.

Flynn, M. and Mok, M. (2002). Catholic Schools 2000 : A longitudinal study of year 12 students in Catholic schools, 1972-1982-1990-1998. Sydney: Catholic Education Commission.

Glaser, B. (1999). The discovery of grounded theory : strategies for qualitative research. New Jersey: Aldine Transaction.

Grace, M. (2003). The use of scripture in the teaching of religious education in Victorian Catholic secondary schools. Unpublished PhD thesis Australian Catholic University.

Groome, T. (1980). Christian religious education: Sharing our story and vision. San Francisco: Harper\& Row.

Groome, T. (1991). Sharing faith: A comprehensive approach to religious education and pastoral ministry. San Francisco: Harper

Habermas, J. (1972). Knowledge and the human interest. London: Heinemann 
Hoge, D., Dinges, W., Johnson, M. and Gonzales, J. (2001). Young adult Catholics: Religion in the culture of choice. Indiana: University of Notre Dame Press.

Hopkins, D., Harris, A., West, M., Aincow, M and Beresford, J. (1997). Creating the conditions for classroom improvement. London: David Fulton Publishers.

Hull, J. (2005). Practical theology and religious education in a pluralist Europe. British Journal of Religious Education, 27(1), 7-19.

Hyde, B and Rymarz, R. (2007). Religious education in Catholic primary schools. Terrigel, NSW: David Barlow Publishing.

ISG (2004)- In search of the good: A Catholic understanding of moral living. Year 12 teacher manual . Ottawa: Canadian Conference of Catholic Bishops

Lovat, T. (2009). What is this thing called religious education? Australia: David Barlow Publishing

Mayer, R. (2005). Cognitive theory of multimedia learning. In R. Mayer (Ed.), The Cambridge handbook of multimedia learning. New York: Cambridge University Press, 31-48.

Mulligan, J. (2005). Catholic education: Ensuring a future. Ottawa: Novelis.

O’Toole, R. (1996). Religion in Canada: Its development and contemporary situation. Social Compass 43(1), 21-43.

Peter, F. 1998. Religion and schools in Canadian Catholic education. Catholic Education; Journal of Enquiry and Practice, (1), 275-298.

Phillips, D and Soltis, J. (2009). Perspectives on learning. New York: Teachers College Press.

Pilarczyk, D. 1986. Dissent in the Church. Origins 16: 175-178

Pollefeyt, D and Bouwens, J. (2010). Framing the identity of Catholic schools: empirical methodology for quantitative research on the Catholic identity of an education institute. International Studies in Catholic Education, 2(2), 193-211.

Pottmeyer, H. (1988). Towards a papacy in communion: Perspectives from Vatican Councils 1 \& II. New York: The Crossroad Publishing Company.

RDECS 1988 -The religious dimension of education in a Catholic school: Guidelines for reflection and renewal. Congregation for Catholic Education 
http://www.vatican.va/roman_curia/congregations/ccatheduc/documents/rc_con_ccatheduc_doc 19880407_catholic-school_en.html

Reigeluth, C. and Carr-Chellman, A., (Eds.), (2009). Instructional-design theories and models: Building a common knowledge base. New York: Routledge.

Rossiter, G. (1982). The need for a "creative divorce" between catechesis and religious education in Catholic schools. Religious Education, 77(1), 21-43

Rossiter, G (1997). A cognitive basis for affective learning in classroom religious education. British Journal of Religious Education. 4(1). 4-11

Rossiter, G. (2010) Perspective on contemporary spirituality: implications for religious education in Catholic schools International Studies in Catholic Education, 2(2), 129-147

Rossiter, G. (2011). Reorienting the religion curriculum in Catholic schools to address the needs of contemporary youth spirituality. International Studies in Catholic Education, 3(1), 57-72

Rummery, G. 1977. The development of the concept of religious education in Catholic schools 1872-1972. Journal of Religious History. (9) 306-319

Ryan, M., \& Malone, P. (1996). Exploring the religion classroom? Wentworth Falls: Social Science Press.

Rymarz, R. (2004). A suggested pedagogy for hard topics in religious education. Journal of Religious Education, 52(4), 31-36.

Rymarz, R. (2007). Who is this person Grace? Some reflections of the teaching of content knowledge in religious education. Religious Education, 102(1), 62-74.

Rymarz, R. (2007A). At the coalface: teaching about Jesus. Journal of Religious Education, 55(1), 12-17.

Rymarz R (2012A). Catechesis and Religious Education in Canadian Catholic Schools. Religious Education - in press

Rymarz, R. (2012). Comparing religious education in Canadian and Australian Catholic high schools: Identifying some key structural issues. British Journal of Religious Education - in press

Schweitzer, F. (2006). Research in religious education: Perspectives for the future. Religious Education 101 (2), 166-169.

Smith, C. and Denton, M.L. (2005). Soul searching: The religious and spiritual lives of American teenagers. New York: Oxford University Press. 
Smith, C. with Snell, P. (2009). Souls in transition: The religious and spiritual lives of emerging adults. New York: Oxford University Press.

Vygotsky, L. (1987). An experimental study of concept development. In R. Rirber and A. Carton (Eds.), Collected works of L.S. Vygotsky: Vol 1. New York: Plenum Press.

Walshe, K (2005). What do young people today really think about Jesus? British Journal of Religious Education 27(1) 65-78.

Zibbertz, H and J. Riegel. (Eds.) 2009. How Teachers in Europe Teach Religion. Berlin Lit Verlag, 